\title{
Chapter 7 \\ Identity Development Among Youth of Vietnamese Descent in the Czech Republic
}

\author{
Andrea Svobodová and Eva Janská
}

Identity and belonging of immigrant children and children of immigrants are important topics in the current debates about migration and integration. In these debates, immigrant youth and children of immigrants are often presented as either a problem group "stuck between two cultures" or as "culture brokers" who translate and transmit the host society's culture to their parents (Fog Olwig 2013). Based on empirical research conducted between 2012 and 2014, this paper discusses dynamics of identity formation among children of Vietnamese descent in the Czech Republic from their own point of view. With 57,000 Vietnamese residing in the Czech Republic, Vietnamese are the third largest immigrant community in the country. Children and youth (up to 26 years of age) of Vietnamese immigrantsboth those born in Vietnam and those born in the Czech Republic-represent approximately $40 \%$ of this population (Kušniráková 2014). Despite these numbers, there has been remarkably little research on the topic of Vietnamese children and youth in the Czech Republic up to now. Existing studies focused mostly on integration in educational settings (Janská 2006; Drbohlav et al. 2007; Janská et al. 2011; Kostelecká et al. 2013).

A critical question that often accompanies this research relates to the identity label these children use: Do they call themselves Vietnamese or Czech? Or does their identify fall somewhere in-between these labels? The latter may be indicated by the term "banana child," invented by the Vietnamese children themselves, which points to the person being "yellow" on the outside but "white" inside. However, our chapter contests the necessity of this identification in the migration context and brings a new perspective to the Czech research environment by focusing more on the process through which the children of Vietnamese immigrants construct a sense of self (Somerville 2008), than on the "identity outcomes."

\footnotetext{
A. Svobodová $(\bowtie) \cdot$ E. Janská

GEOMIGRACE, Charles University, Prague, Czech Republic

e-mail: plackova.andrea@seznam.cz 
It is commonly assumed that there are differences between the identity perceptions and identification processes of first generation immigrants and their children. To begin with, these "migrant children" are not migrants, although the term "second-generation migrants" is widely used. Some of them have been born in the Czech Republic or came to live here at a very early age, with little if any recollection of their previous homes. They have gone through the Czech school system, mastered the language, often form very steady friendships with Czech peers, and are more or less integrated into the mainstream population. That is why some believe that, unlike for their parents, ethnicity should no longer be of great importance to them (Gordon 1964). But if it is not ethnicity, then what is it that shapes the identity perception of these children?

According to Crul and Schneider, the most important driving forces behind most of the actions of immigrant children and children of immigrants are age, gender, educational levels, and other "common" factors, not the fact that they are children of immigrants (Crul and Schneider 2010; Portés and Rumbaut 2001). We agree with Crul and Schneider that the role of ethnic and migration background has been exaggerated in the study of immigrants and their offspring in the past years, especially when it comes to questions of immigrants' integration (Crul and Schneider 2010). But at the same time we also believe that migrant background and the culture of their parents play a very important role in the lives and identity formation of these children (Min 2002; Kibria 2002). ${ }^{1}$

The fact that these children are growing up in a social space we call "migrancy" means that they have to face different challenges in their lives than their peers from the majority society. To put it simply, we all reflect upon our identity sometimes (Jenkins 2004) and adolescence is a hard time for almost everyone, but in the case of immigrant children and children of immigrants, there are issues that make it at least more complicated, if not harder (Huang 1994; Chow 1999, 20).

This chapter aims at a broader understanding of how the identities of these children are formed by adopting the "growing up in migrancy" concept which views "migrancy" not only as a social space, in which children are growing up (even when they are not migrants, but because their parents or even grandparents once were), but also as a social category, which has the same impact on these children and young people as, for example, social class or gender (Näre 2013). We look at how these young people contest identities for themselves while trying to come to terms with the fact that they are growing up "in migrancy" and "between two cultures."

\footnotetext{
${ }^{1}$ Min says that: "despite the tendency among Asian American scholars to downplay their importance, primordial ties, especially their parents' home country and its culture are of a great significance for the second generation."
} 


\section{Vietnamese in the Czech Republic}

Vietnamese migration to the Czech Republic has a long tradition. Diplomatic relations between Vietnam and the former Czechoslovakia were established in the early 1950s when Czechoslovakia provided temporary refuge to Vietnamese war orphans. Subsequent waves of Vietnamese migrants came to Czechoslovakia on the basis of reciprocal agreements. In the 1970 and 1980s, bilateral agreements on scientific and technological cooperation brought apprentices, workers, and exchange students to be trained in the textile, engineering, and paper industries. The aim of the Vietnamese government was to bring back a qualified labour force from the ČSSR to war-torn Vietnam to assist in its renewal. Between 1979 and 1985 , when Czechoslovakia had a shortage of local labour, a large influx of labour migrants from Vietnam came to the country.

A temporary rupture in Czech-Vietnamese relations occurred after 1989, when the transformation of the Czech economy forced many Vietnamese to return home. After treaties for the professional training of Vietnamese citizens in the Czech Republic and mutual employment were renewed in 1994, some Vietnamese began returning to the Czech Republic. The 1990s were therefore a time when people typically made use of earlier contacts and knowledge of the Czech environment. These people were followed by their relatives and friends as well as by people who came to the country with the assistance of intermediaries or through recruitment agencies. From 2006, the number Vietnamese migrants working on the basis of regular employment contracts has increased significantly. Most of these Vietnamese migrants are factory workers. The main reason for this was a legal adjustment in 2004 that allowed intermediary agencies to hire foreign workers (Janská 2006).

Vietnamese who settled in the Czech Republic after the fall of communism often drew on community networks to launch their careers in business, especially in retail. Initially, Vietnamese immigrants clustered in the country's border regions and mainly sold textiles, electronics, and groceries. From this period comes the common stereotype of a Vietnamese migrant as a "stall-keeper." Recently Vietnamese businesses have been moving out of the market into retail space and extending into more varied branches (Martínková 2008; Hofírek and Nekorjak 2009). Vietnamese have opened nail salons, dry-cleaners, and small restaurants offering authentic Vietnamese food. They are also working as translators, in social care, and some have set up successful medium scale companies (Martínková 2008; Pechová 2007). As the children of these migrants started to attend Czech schools a new stereotype emerged. This time it was the more positive stereotype of a "model minority," which suggests that all Vietnamese are overachievers and perfect students. In the following section, we show that the labels describing Vietnamese as stall-keepers or a model minority are insufficient, and that the reality is much more complex and the experiences and identities of young Vietnamese are much more diverse. 


\section{Stories as Entrance to Personal Identity}

This chapter is based on analysis of fourteen "life-stories" (Atkinson 2002) conducted among young people of Vietnamese descent. The interviews were conducted by Andrea Svobodová between 2012 and 2014 in different parts of the Czech Republic. In the interviews, the young people produced narratives about their lives from their own perspective. By paying attention to the thematic content and structure of their life stories, it was possible to understand the meaning that they are giving to their lives (Kacen 2002). In selecting the respondents, two criteria have been taken into account. First was age, which was limited to $16-29 .^{2}$ Second was the place of birth. Here the respondents were either born in the Czech Republic or born in Vietnam, but lived in the Czech Republic from an early age (before the age of twelve). We choose to include both these groups since they share many linguistic, cultural, and developmental experiences (Zhou 1997). The interviews were further limited to young people whose parents are described in the literature as "old settlers" (Brouček 2003). Today, these people represent an economically successful and well-integrated group of Vietnamese migrants in the Czech Republic (Kušnirákova et al. 2013). In order to protect their anonymity while retaining the human element evoked by proper names, we have given all the research participants Vietnamese pseudonyms with no connection to their real names.

\section{The Stable Point of Identity Development}

Adolescence, a turbulent time for most young people, is also a time of reflection on and formation of identity (Jenkins 2004). Research indicates that in the case of immigrant children and children of immigrants, identity issues are more complex (Huang 1994; Chow 1999; Portés and Rumbaut 2001; Kibria 2002; Min 2002). Young people who participated in this study are not an exception. Most of them have, at one point in time or another, asked themselves: where do I belong? Am I more Vietnamese or more Czech? Even if some of them cannot answer these questions, it is incorrect to say that they are "stuck somewhere between two cultures." As the presented research shows, the period of struggle to identify with the culture of their parents or the culture of the country where they grew up is just one of the stages in their lives where their feelings and opinions about themselves evolve and change over time.

The understanding of identity as something socially constructed, fluid, and changeable in time and space corresponds with the constructivist perspective on identity development (Berger and Luckmann 1999). This perspective is very often presented in opposition to the essentialist perspective, which perceives identity as

\footnotetext{
${ }^{2}$ This stage of life described by Lee and Zhou as an overlapping stage between childhood and adulthood is marked by exploring and forming of one's identity (Ericsson 2068).
} 
something fixed, biologically given, omnipresent and ahistorical, waiting to be discovered. By paying closer attention to these concepts, we can see that both perspectives understand identity as something unstable and developing over time. The difference is that from the essentialists' point of view this unstable process reaches a stable point (often during the transition phase from adolescence to adulthood) (Erikson 1974), while from the postmodernist view this can never be the case (Bauman 2001). The question is: what then is the search for identity about if there is no stable ground that we can build on Brubaker and Cooper (2000); Jenkins (2004) and Huang (1994) both present an interesting answer to this question. Jenkins says that the inclination of human nature to categorize the world and make it more reachable and graspable is something that naturally derives from how human minds work. From his point of view, the "omnipresent and natural" part of identity is not the identity itself but the search for it (Jenkins 2004). To Huang (1994), identity combines change and consistency. The stable, persistent part of identity "resides in the identity salience hierarchy," and the process of choosing an identity, which is most appropriate to the given situation, is at the basis of coherent ethnic identity (Huang 1994, 48).

\section{The Dynamic Nature of Migrant Children's Identities: Negotiating Ethnic Identity Between Highly Polarized Expectations}

The main focus of the presented study was not on ethnic identity, but on identity as such. That is why no direct questions about ethnicity were posed to the research participants in the first part of the interview. This resulted in a production of narratives which were different in many aspects. However, questions of ethnicity, culture, and ethnic identity struggles were always present, and proved to be very important in the lives of the interviewed children and young people. What also became clear from these narratives was the situational and dynamic character of ethnic identity, which developed and changed over time.

In her qualitative study of ethnic identity among second-generation Asian Americans, Hung Cam Thai shows that as they grew up, her research participants were marked by feelings of marginalization, and that during childhood and adolescence they often experienced feelings of not belonging to either their "old" or "new" social worlds. On reaching adulthood, these feelings often changed as they started to be more interested in their cultural heritage. As they accepted their ethnic and racial identities, they became more confident about themselves and more proud of their ethnic and racial backgrounds (Thai 2002). Although we believe that identity development stages do not capture all the facets and the dynamic nature of the ethnic identity of every individual child, we think they are useful because they show how ethnic identity continually changes and grows. These stages should also not necessarily be viewed as lineal because young people often revert back and 
forth between them (Phinney 1989). The results of the presented research conducted among the children of Vietnamese descent show many similarities with the Asian Americans studied by Thai, although there are also some differences.

\section{From "Blessed Unconsciousness" to Rejecting the Ethnicity Which is Different from the Mainstream}

In order to examine how ethnic identity changed over time, we want to present the case of Lin. Lin is a 27 year old woman who was born in the Czech Republic, left for Vietnam, and came back again at the age of ten. ${ }^{3}$ Lin, like most of the other study participants, grew up in a place where there were not many other Vietnamese, or if there were, they did not live in visible ethnic communities. She went to schools with predominantly Czech pupils, made Czech friends and sometimes spent more time with her Czech nanny than with her own parents. ${ }^{4}$ Searching through her childhood memories, she reconstructs four different stages that marked changes in her perception of how she thought about herself and her ethnicity. As first she mentions the stage of early childhood "when the child isn't aware of any differences or doesn't care about them, she/he knows that she/he is less strong and (there are reasons) why the children bully him/her, but he/she doesn't realize that it is because of his/her nationality," she said.

This period of "blessed unconsciousness" ended in early puberty (between thirteen and fifteen years of age), when she started to realize that there was something "different" about her and began asking herself questions like "So who are you going to be? Are you going to be Vietnamese or Czech? Do you want to be different or not?" Lin experienced the pressure to conform to the majority in this stage of life (Min 2002) very strongly. She tried to "be and act like others," "to be Czech." To a certain degree, this effort to fit in was also accompanied by her rejection of the parental culture and ethnicity, which was perceived as different from the mainstream, even inappropriate in some cases (Min 2002). Lin's parents, like the parents of most of the other respondents, were described by her as strict, conservative, hardworking, overprotective, too concerned with her school achievements and future, and sometimes not very empathetic. They expected Lin to honour certain traditional Vietnamese values: respect the elderly, be polite, put family first, fulfil her family obligations, be industrious, and strive for self-cultivation and improvement. Lin thought of these attitudes and values as culturally bounded, connected with the Vietnamese way of living, and different from the more "individualistic" Czech lifestyle which she was exposed to on a daily basis. The result was her contestation of her parents' ideas, which she saw as old-fashioned and limiting her freedom. Her growing-up was therefore marked by

\footnotetext{
${ }^{3}$ We choose this example because of the great self-reflectivity in Lin's story which allows us to see how this young girl interprets her feelings and behaviour from her perspective.

${ }^{4}$ The phenomenon of nannies, which is widely spread among the Vietnamese living in the Czech Republic, has been studied by Adéle Souralová (Souralová 2013).
} 
conflicts with her parents over dating, going out in the evening, or staying overnight at friends' homes, which is something acceptable in the Czech society but not approved of in Vietnamese families.

\section{"Ethnic Revival": The Renewed Interest in the Parents' Ethnicity and Culture and the Change of Social Circle}

Later we see Lin maturing and starting to view her parents and their culture from a different perspective, which makes her question her identity again.

Then comes the period, around the age of sixteen, seventeen, when you start to turn back to that culture, you say to yourself that you aren't Czech at all, because you have completely different problems that your classmates couldn't understand, you are being raised differently. Now you want to go back to that core, why it is that way, why your parents are raising you that way, why they have these opinions. At the age of thirteen you might say to yourself, they are stupid, but at the age of eighteen you want to understand why they do what they do.

In this period of her life, she "decided to be Vietnamese" and started to immerse herself in the Vietnamese language and culture wanting to find out more about her "roots." Her choice was influenced not only by the renewed interest in her "roots," but also by the pressure from her parents. From what she is saying, we can surmise that she saw her ethnicity as something not voluntary: "I chose this because I thought that it is right, that it should be like that. I look Vietnamese, I have Vietnamese parents, and I am comfortable with Vietnamese culture. I started to be really interested in all this," she said. At this time, she also started creating new friendships and strengthening old relationships with her friends of Vietnamese descent. ${ }^{5}$ The reason for this was not "ethnicity," but rather shared experiences of growing up. Czech kids usually did not understand why she could not go dancing at the age of sixteen like anybody else or why she had to help her parents in their shop on weekends, but in the eyes of the Vietnamese friends, this was something quite normal and did not need to be explained.

\section{Contesting the Dual Reference Frame of Identity and Belonging and Embarrassment of Both Cultures}

Learning more about the culture of her parents helped Lin to become more confident. However, her identity development did not end at the stage of "ethnic revival." In her story there is a fourth stage, which she describes as a stage of

\footnotetext{
${ }^{5}$ This is a phenomenon which we refer to as "changing of the social circle" occurs not only in the narratives of most the other research participants, but which has been observed also in the case of Asian American youth (Min 2002; Kibria 2002).
} 
broader options and independence, which came at the time when she left her parents' home and went to study at the University in Prague. She describes it as follows:

\begin{abstract}
When I went to study at the University, when I broke away from my family, started to live alone and to meet other people, at that time I said to myself, "Look there are also other options, you don't have to be only Czech or only Vietnamese." I can choose what I want to, but I have to be able to work with it, and to fight for it. So I started to mix it up more, which caused more and more troubles at home, but I am not small any more, having to put up with it. I am not dependent any more, financially nor psychologically. And this now suits me the best, that I am stronger and more independent.
\end{abstract}

As we can see, the stage of so-called "ethnic revival" was only a stage in her life when she needed to further process the problems connected with her ethnic origin. Once these were resolved, she did not wish to see her Vietnamese friends more often than her Czech friends, and she wants to embrace both cultures without feeling the need to choose between them. Lin's narrative clearly shows that: "contrary to widespread folk and political ideas about identities, belonging is never confined to just one category" and that "It is also not necessarily put in either/or terms" (Crul et al. 2012, 290). On the contrary, people can have multiple identities, from which they can more or less freely and selectively use and combine according to the situation (Min 2002; Bauman 2001; Hall 1996; Huang 1994; Eriksen 2002).

The same could be said about most of the other children and young people who participated in the research. Some of them were very rebellious, but even these rebellious kids never went so far as to reject completely the traditions that their parents tried to pass on to them. They did not put the "collectivistic" and "individualistic" values against each other, but rather next to each other by constructing their identity around the idea that they are special, because of the privilege of seeing life from different angles. They definitely cannot be seen as "just" cultural brokers who only translate the culture of the migrant country to their parents. They should rather be seen as active members of the society who consciously create a culture of their own (Hirschfeld 2002).

These findings bring us to the theoretical background of the study and the question if there is a stable part of identity development that can be reached. The narrative of Lin, along with the narratives of other research participants which evolved in the same way, suggest that the "stable part" of their identity perception is in the way they are selecting among different identities according to the situation, which for them presented a stable conceptual framework. (Huang 1994, 48). 


\section{Partner Choice and Family Expectations}

The great weight of parental expectations was one of the most prominent themes in the story told by Lin. Most of the other interviewed children and young adults spoke extensively about how their parents' views on how they should be and behave influenced them and sometimes made their lives difficult. One of the situations when young people are expected "to negotiate differences between their parents' cultural preferences and their own" is the choice of a romantic partner (Crul et al. 2012). Among the research participants, this process of negotiation varied with the individual. There were those with a Czech partner who had to overcome many obstacles and disapproving reactions of their parents, but the majority did not encounter these problems, simply because they chose to date or to marry a co-ethnic. Some of them acknowledged that they respected-consciously or unconsciously - their parents' wishes and preferences. Lin is a case in point. She said that her parents never told her not to marry a European man: "Like they told me to marry whomever I wanted, but in the end, they would probably be quite surprised if I would bring a European home," she says.

The situation of choosing a partner does not always have to be seen as a struggle between the expectations of the children and the parents. Sky, a girl who was born in Vietnam but has lived in the Czech Republic from the age of 5, made her statement clearly. From her point of view, it is not so important whether her spouse be Vietnamese or Czech ("race doesn't matter"). What really matters is culture, mentality, and common experiences of growing up, which represent important factors behind the "success" of any relationship and this she absolutely will not undervalue. From this point of view, Sky is not going to marry somebody only because of her parents' wishes, but will make her choice taking into account all the important aspects of "her" personal situation:

I am always saying that I wouldn't mind having a Czech boyfriend, but it would have to be somebody who is going to be interested in the Vietnamese culture, who for example is going to learn Vietnamese and who will know about Vietnamese culture, because if he knows the language then he will be able to communicate with my parents, even though they both speak good Czech. But through studying the language one learns how to understand the mentality of that nationality and that is very important, because if it wasn't like that then I would understand him because I grew up here and I know how it goes, but it wouldn't work in the opposite direction, and I think to have a good relationship you need to have mutual understanding from both sides.

Another interesting perspective on co-ethnic partner choice was provided by two young women, Jana and Phuong, both aged twenty-one and both born and raised in the Czech Republic. After some negative experiences at school, both concluded that Czech boys did not find them attractive. This feeling led them to a decision that it would be better to look for a partner among the young people of Vietnamese descent. From their point of view, they were not pushed by their parents but rather by the circumstances, such as their negative experiences with Czech boys. 


\section{That Is Not Who I Am: Contesting One's Identity Against Generally-Held Stereotypes}

For children of Vietnamese migrants in the Czech Republic, growing up in "migrancy" does not only mean that they have to cope with different kinds of expectations from their parents and majority society. Growing up in "migrancy" also means that they have to cope with prejudice and racism. While contesting the ascribed identities in an environment full of prejudice, many of the research participants tried to distance themselves from the group of what they called "new wave" Vietnamese migrants who have come to the Czech Republic in the past ten years (Pechová 2007; Kušniráková et al. 2013) by drawing on stereotypes used in the media. The stereotypes describe this group of Vietnamese as uneducated peasants, drug dealers and criminals. This strategy of so-called "disidentification" which is described by Goffman in Stigma (1986) does not have to be applied in direct contact with a person who shows some aggressive behaviour, for example by making racist comments. On the contrary, the research findings show that this urge to defend oneself is something almost omnipresent in one's mind. Here we can find parallels between the cohort in our study and the second generation African Americans studied by Mary Waters in the United States. These young people also did not want to be identified with the society's negative portrayals of "poor blacks" and while trying to differentiate themselves from them, they also built on stereotypes of lower-class African Americans, such as lack of discipline and work ethic (Waters 1994). Due to the fact that recent migrants to the Czech Republic are supposed to be from poorer economic backgrounds (Kušniráková 2014; Pechová 2007), the reason that they wanted to distance themselves from this group of immigrants could, as Kibria says, "be based not only on their aversion to "foreignness' but also on their own class identification" (Kibria 2002, 91).

Other stereotypes that the research participants built on while distancing themselves from other Vietnamese were those that in their view represented the classical "conservative and less developed" Vietnamese society. For example, while talking about the choice of partners the so-called "Vietnamese traditional role" of the spouse was viewed as something that did not suit them. While most of the female research participants preferred to date Vietnamese men born or raised in Czech Republic rather than Czechs, they all agreed that they would definitely choose a Czech above a man born and raised in Vietnam. In their eyes, these men were too traditional and would probably not be able to cope with their "Westernized" manners. As Sky says:

There is just something I wanted to add, that when we choose partners, we need to have these European Vietnamese, actually if I can say it like that, we are this "one-and-half" generation, we have this Czech and Vietnamese mentality combined, but if someone was purely Vietnamese, without this Czech experience, then we couldn't get along, because we are more emancipated and liberal in some opinions. And maybe some Vietnamese guy, would not get over it, if I can say it like that. 
The very experience of growing up in migrancy makes a big difference. From their recollections of Vietnam and in the way the research participants reflect upon their visits of their ancestral country, we can see that life and people there are viewed as different and distant from them and their lives in the Czech Republic. Linda explained the reason why she is happier to live in the Czech Republic rather than in Vietnam as follows:

I am happy that I grew up here in the Czech Republic, rather than in Vietnam. Because I see it in the case of my nieces living there. For example, my uncle makes a lot of money in Vietnam and there you are either very poor or very rich. And my uncles, they all have lot of money and they have children of my age, who use drugs and these kinds of things, because that is something that is like very trendy there, very European, so going to parties, drinking and those kinds of things.

Another stereotype that the research participants build on while constructing their identity is the one which presents Vietnamese in the Czech Republic as "closed, incommunicative and segregated" (Brouček 2003, 4, 26). During his narrative Viet Van, a young man of 21, born in the Czech Republic, stressed that his family is not a "classical Vietnamese" family. Instead, he described his parents as open and communicative, which he illustrated by saying that his father often goes to pubs with his Czech neighbours.

My father, usually after work, visits local pubs with his colleagues, he isn't that kind of type, like it is said that Vietnamese are reserved. My father absolutely isn't like that, he, you know, he just lives a Czech life here. He goes with them to the pub, chats, sometimes he even doesn't come home for dinner.

The model minority stereotype (Kibria 2002; Waters 2001) paints all Vietnamese children as super-smart overachievers. Research participants challenged this stereotype by emphasizing that they are not such intellectual types. Study participants also contested the presumption that they had strict Vietnamese parents, because they did not want to be seen as obedient people without any free will. As we can see, the question of "who we are" is often closely related to the question of "who we are not." The desire to positively evaluate one's self has led the research participants to the construction of cognitive boundaries that differentiate those who are similar to them from those who are different (Rosenberg and Kaplan 1982). What we also understood from the narratives of the research respondents is that they did not gain an understanding of themselves only by stressing differences and distancing themselves from others, but rather through interaction with "different" or "same" others (Jenkins 1997). Positive identification and disidentification were happening at the same time (Jenkins 1997). For example, when they were trying to distance themselves from a group of Vietnamese whom they saw as "more conservative," while at the same time identifying themselves with those of Vietnamese descent who were more like them, better educated and more "Westernized." 


\section{Symbolic Ethnicity and Race}

Another important question that should be discussed when talking about ethnic identity is the question of whether ethnicity is a matter of choice and how it is connected to race. According to Gans (1979), ethnicity in time becomes optional and people who keep ties with their ethnic identities are making this choice voluntarily because they can gain something positive from it. But Gans formulated his theory of "symbolic ethnicity" in reaction to the so-called "ethnic revival" among the third generation "immigrants" in the U.S. and the group he was referring to were "White" (non-racialized) immigrants. The same counts for Richard Alba, who suggests a great deal of choice in the case of ethnicity (Alba 1990). On the other hand, authors, who studied "non-White" (racialized) minorities in the U.S. (Waters 1990, Kibria 2002), present a completely different picture when talking about symbolic or voluntary ethnic identity. In the case of Asians, Nazli Kibria argues that "a part of their ethnicity is not optional and they cannot, in the perception of others, unlike white ethnics who practice symbolic ethnicity, slip in and out of 'being ethnic"" (Kibria 2002, 101).

For most of the study participants, ethnicity was not always a matter of choice. Some of them said that this was because even if they would try to "slip out" of being "ethnic," others would not let them because they would always see them as different or foreign. This presumption of foreignness in the eyes of others does not always have to be articulated directly to be truly felt. For example, compliments paid to the research participants by other people about their perfect knowledge of the Czech language, or the estimation that they should be "experts" on the topic of Vietnamese culture aroused awkward feelings among these young people, putting their identities in question. On the other hand, not everybody experienced ethnicity as something involuntary. For example, Karel, who dated a Czech girl and had almost only Czech friends, said that he had never experienced the feeling of being different. "It is true," he said, "that in the beginning, when people don't know me yet, they ask about my origin." To him, however, this was something natural and normal, which did not constrain him in claiming the identity of his choice. "Of course I know I look different, but, you know, I actually never think about it," he said. As we have seen earlier in this chapter, race was also not a prominent issue in the case of making friends or choosing a suitable partner. What really mattered with this decision were culture, mentality, and common experiences of growing up in migrancy. Although some societal issues and involuntary ascriptions associated with racialized or non-white identities (Waters 1994) were felt by some of the interviewed children and young adults, the question of race did not constitute a major concern for them. 


\section{It Is Not All About Ethnicity: Contesting the Ethnic Majority-Minority Framework}

We have shown that the question of ethnicity plays an important role in the ways the interviewed youth perceive and construct their identities. However, there are other equally or even more important factors, common to all young adults irrespective of their origin, that in the eyes of the research participants shaped them into who they are. First love (reciprocated or not), first "serious" relationships, friends, physical distinctions or defects (congenital or caused by injuries), or even travel experiences, experiences of living abroad, and hobbies that turned to passions all had a big influence on the lives of the study participants and their identities. Furthermore, the turbulent relationships with their parents should not only be seen as something connected solely to struggles caused by cultural gaps, but as something that normally occurs in the relationship between child and parent, irrespective of ethnic background. One of the themes that appear through Karel's narrative is that of his first serious relationship. His love for this Czech girl and the things that he learned from her, as he put it, introduced him to a radically different perspective and led him to re-evaluate his outlook on life and ideas about himself. Marek (twenty-seven), who came to Czech Republic at the age of nine, also mentions how his love for a girl while he was in primary school presented the main "motivator" behind almost all his actions.

In the case of forming my own "me," I fell in love with a girl, I was into her from the age of nine and it took me more than three years to keep lying to myself about that I was not good enough, like I was telling myself that I am not sportive enough, smart enough and so on. This actually kept me going, kept me motivated in perfecting myself. Every time she declined my "offers," I was partially sad, partially pissed off and because she turned me down thirty-five times in all, I at that time realized that you cannot get everything even if you really try hard. Because that was what I was thinking before, before I met this girl. So she really influenced me and I changed in the way that I wasn't that ambitious, choleric guy anymore but became more relaxed.

Ethnicity clearly is not always that important and there are many situations when it does not matter at all (Crul and Schneider 2010; Eriksen 2002). In order to define themselves, people can choose from different identities and statuses, according to the social situation (Huang 1994). Even when it is relevant, ethnicity is not always the most relevant factor (Eriksen 2002). From this point of view, the idea that migrant or ethnic minority children and youth are essentially "different" from the "other" majority kids becomes irrelevant. 


\section{Conclusions}

This chapter has touched on some aspects of identity perception and formation among young adults of Vietnamese ancestry living in the Czech Republic. The purpose was to show how these young people create an identity for themselves while growing up in "migrancy." We were particularly interested in the question of whether these children and young people face identity struggles more often, or in different ways, than children who are not growing up in immigrant families, as well as what role ethnicity, culture, and migrancy play in their identity construction. Contrary to the general assumption that ethnic identities in the second and following generations become less salient (Hall 1996), ethnicity turned out to be very important for the youth in our study. On the other hand, it was also obvious that not all their actions and views were motivated by their families' migration experiences and/or ethnic heritage. We can therefore conclude that their identities derive from both ethnic and non-ethnic identifications (Huang 1994), within the social space of migrancy.

Although we, as researchers, regard identities as socially constructed, the research participants did not always share this view. On the contrary, ethnicity was very often seen and presented as given by nature, as we, for example, could see when the research participants ascribed some character traits of their parents or even themselves to the fact that they were Vietnamese. We do not wish to suggest that identity and ethnicity are something primordial and fixed in an objective kind of way, but rather to support Clifford Geertz (1973, 255-310), who says that it is often seen and experienced as such by the members of the ethnic communities themselves.

Through capturing the fluid and dynamic nature of ethnic identity perception in the life stories of the research participants, we also wanted to challenge the dominant Western notions of a fixed and stable nature of childhood and youth. Here we especially contested the assumption of cultural essentialism that constructs children of migrants as trapped between two cultures by demonstrating that the interviewed youth did not feel comfortable with the idea that they should choose between the identity of their parents and the identity of the majority. According to the way they see themselves, the idea of multiple ethnic identities, from which they can freely and selectively choose according to the situation, makes much more sense. From this point of view, the inner struggle that these young people went (or were still going) through was not a consequence of the inability to choose one "culture" above the other, but rather a result of the societal pressure put on them by their parents and by members of the majority population that they should do so.

Acknowledgments The presented research was funded by a financial grant project from the Charles University Foundation, GA UK, no. 685812/2012 "Migrant descendants in Czech Republic-Integration, Identity and Belonging." 


\section{References}

Alba, R. D. (1990). Ethnic identity: The transformation of white America. New Haven, London: Yale University Press.

Atkinson, R. (2002). The life story interview. In: J. F. Gubrium \& J. H. Holstein (Eds.), Handbook of interview research. Context and method (pp. 121-141). New York: Sage Publishing.

Bauman, Z. (2001). Identity in the globalizing world. Social Anthropology, 9, 121-129.

Berger, P. L., \& Luckmann, T. (1999). Sociální konstrukce reality. Praha: Centrum pro studium demokracie a kultury.

Brouček, S. (2003). Aktuálni problémy adaptace vietnamského etnika v ČR. Praha: Etnologický ústav AV ČR.

Brubaker, R., \& Cooper, F. (2000). Beyond ethnicity. Theory and Society, 33(1), 31-64.

Chow, C. S. (1999). Leaving deep waters. New York: Penguin Books.

Crul, M., \& Schneider, J. (2010). Comparative integration context theory: Participation and belonging in new diverse European cities. Ethnic and Racial Studies, 33(7), 1249-1268.

Crul, M., Schneider, J., \& Lelie, F. (Eds.). (2012). The European second generation. Does the integration context matter? IMISCOE research. Amsterdam: Amsterdam University Press.

Drbohlav, D., Dzúrová, D., Černík, J. (2007). Integrace cizinců, žáků základních a středních škol, do české společnosti: př́klad Prahy. [původní článek]. In Geografie, Sborník (Vols. 112, No.2, pp. 161-184).

Eriksen, T.H. (2002). Ethnicity and nationalism: Anthropological perspectives (2nd edn.). London: Pluto Press

Erikson, E. (1974). Identity: youth and crisis. New York: Norton.

Fog Olwig, K. (2013). Migration and care: Intimately related aspects of Caribbean family and kinship. In L. Baldassar \& L. Merla (Eds.), Transnational families, migration and the circulation of care: Understanding mobility and absence in family life (Vol. 29, pp. 133-148). Routledge Research in Transnationalism.

Gans, H. J. (1979). Symbolic ethnicity: the future of ethnic groups and cultures in America. Ethnic and Racial Studies, 2(3), 1-20.

Geertz, C. (1973). The integrative revolution: Primordial sentiments and civic politics in the new states. In C. Geertz (Ed.), The interpretation of cultures. Selected essays (pp. 255-310). New York: Basic Books, Inc. Publishers.

Goffman, E. (1986). Stigma. New York: Touchstone.

Hall, S. (1996). Introduction: Who needs 'identity'? In S. Hall \& P. Du Gay (Eds.), Questions of cultural identity. London: Sage Publications.

Hirschfeld, L. (2002). Why don't anthropologists like children? American Anthropology, 104(2), 611-627.

Hofírek, O., \& Nekorjak, M. (2009). Vietnamští imigranti v českých velkolměstech-integrace přistěhovalců z Vietnamu. In M. Rákoczyová \& R. Trbola (Eds.), Sociální integrace pristěhovalců v České republice. Praha: Slon.

Huang, L. N. (1994). An integrative view of identity formation: a model for Asian Americans. In E. P. Salett \& D. R. N. M. C. I. Koslow (Eds.), Race, ethnicity and self-identity in multicultural perspective. Washington, DC: National MultiCultural Institute.

Janská, E. (2006). Druhá generace cizinců v Praze: př́klad dětí z mateřských školek a jejich rodičů. Geografie-Sbornik České geografické společnosti, 111(2), 198-214.

Janská, E., Průšvicová, A., \& Čermák, Z. (2011). Possibilities for researching the integration of Vietnamese children in Czechia: The example of Prague-Kunratice elementary school (Možnosti výzkumu integrace dětí Vietnamců v Česku: Př́ílad základní školy Praha-Kunratice.). Geografie, 116(4), 480-496.

Jenkins, R. (1997). Rethinking ethnicity. Arguments and explorations. London: Sage Publications. Jenkins, R. (2004). Social identity. London: Sage Publications.

Kacen, L. (2002). Supercodes reflected in titles battered women accord to their life stories. International Journal of Qualitative Methods, 1(1), 2-21. 
Kibria, N. (1993). Family tightrope: The changing lives of Vietnamese Americans. New Jersey: Princeton University Press.

Kibria, N. (2002). Becoming Asian American. Second generation Chinese and Korean American identities. Baltimore: The Johnson University Press.

Kostelecká, Y., Kostelecký, T., Kohnová, J., Pokorná, K., Vojtíšková, K., \& Šimon, M. (2013). Žáci cizinci v základních školách: Fakta, analýza, diagnostika. Karlovy, Praha: Pedagogická fakulta Univerzity.

Kušniráková, T. (2014). Vietnamci v Česku a ve světě- migračni a adaptační tendence. Slon: Praha.

Kušniráková, T., Plačková, A., \& Tran Vu, V. A. (2013). Vnitřní diferenciace Vietnamců-pro potřeby analýzy segregace cizinců $\mathrm{z}$ třetích zemí. Výzkumná zpráva-rozšířená verze, Ministerstvo pro místní rozvoj, Praha.

Martínková, Š. (2008). Sociabilita vietnamského etnika v Praze, In Uherek Z.,Korecká Z., Pojarová T. et al., Cizinecké komunity $z$ antropologické perspektivy, vybrané prípady významných imigračnich skupin v České republice. Praha: Etnologický ústav AVČR, 167-210.

Min, P. G. (2002). The second generation-ethnic identity among Asian Americans. Walnut Creek: AlltaMira Press.

Näre, L. (2013). Migrancy, gender and social class in domestic labour and social care in Italy: An intersectional analysis of demand. Journal of Ethnic and Migration Studies, 39(4), 601-623.

Pechová, E. (2007). Migrace z Vietnamu do české republiky v kontextu problematiky obchodu s lidmy a vykořistováním. Praha: La Strada a MV.

Phinney, J. S. (1989). Stages of ethnic identity development in minority group adolescents. The Journal of Early Adolescence, 9(1-2), 34-49.

Portés, A., \& Rumbaut, R. G. (2001). Legacies: The story of the immigrant second generation. Oakland: University of California Press.

Rosenberg, M., \& Kaplan H. A. (1982). Social psychology of the self concept. Arlington Heights, IL: Harlan Davidson.

Somerville, K. (2008). Transnational belonging among second generation youth: Identity in a globalizing world. Journal of Social Science, Special, 10, 23-33.

Souralová, A. (2013). Children of Vietnamese parents brought up by Czech nannies: Reconstructing and redefining family ties. In Gender and migration: Critical issues and policy implications (pp. 48-56). London: London centre for social studies.

Thai, H. C. (2002). Formation of ethnic identity among second-generation Vietnamese Americans. In P. G. Min (Ed.), The second generation-ethnic identity among Asian Americans (pp. 5385). Walnut Creek: AlltaMira Press.

Waters, M. C. (1990). Ethnic options: Choosing ethnic identities in America. California: University of California Press.

Waters, M. C. (1994). Ethnic and racial identities of second generation black immigrants in New York city. International Migration Review, 28(4), 795-820.

Waters, M. C. (2001). Black identities: West Indian immigrant dream and American realities. Cambridge, Massachusetts: Harvard University Press.

Zhou, M. (1997). Growing up American: The challenge confronting immigrant children and children of immigrants. Annual Review of Sociology, 23, 69-95. 
Open Access This chapter is licensed under the terms of the Creative Commons Attribution-NonCommercial 2.5 International License (http://creativecommons.org/licenses/by-nc/ $2.5 /$ ), which permits any noncommercial use, sharing, adaptation, distribution and reproduction in any medium or format, as long as you give appropriate credit to the original author(s) and the source, provide a link to the Creative Commons license and indicate if changes were made.

The images or other third party material in this chapter are included in the book's Creative Commons license, unless indicated otherwise in a credit line to the material. If material is not included in the book's Creative Commons license and your intended use is not permitted by statutory regulation or exceeds the permitted use, you will need to obtain permission directly from the copyright holder. 